\title{
Recently aspects regarding International Auditing Standard 200 „Overall Objectives of the Independent Auditor and the Conduct of an Audit in Accordance with International Standards on Auditing”
}

\author{
Daniel Botez, Associated Professor Phd., University „Vasile Alecsandri” of Bacau
}

\begin{abstract}
:
The purpose of an audit is to enhance the degree of confidence of intended users in the financial statements. This is achieved by the expression of an opinion by the auditor on whether the financial statements are prepared, in all material respects, in accordance with an applicable financial reporting framework.

The International Standard on Auditing 200 (ISA 200) deals with the independent auditor's overall responsibilities when conducting an audit of financial statements in accordance with International Standards on Auditing (ISAs).
\end{abstract}

\section{Keywords:}

financial statements, financial audit, International Standards on Auditing

The first decade of XXI century aa brought unprecedented challenges to the accounting professionals. Financial scandals that have exploded at the beginning of this period have set new coordinates harmonization processes, internationalization of standards and economic globalization in general. Europeanization process based on the need for EU enlargement was directly influenced by changes in international references.

Over all these, the economic crisis has become a global character and influence, in grades and sizes, all stakeholders in the organic processes. One of the key players in these events is accounting profession, which ensures the preparation of financial information underlying economic decisions, and increasing the credibility of this information.

As a representative of the international accountancy profession, IFAC (International Federation of Accountants) has been concerned throughout this period of recovering, at certain times, maintain and increase user confidence in the services offered by the accounting profession. A key effort in this direction requires regular review of professional standards.

Last significant revision of the International Auditing Standards (ISAs) was completed in April 2009 with the publication by IFAC to form new professional standards for audits and review. A fundamental change them is to set a standard content of each of them. Thus, each standard contains the following contents:

- Introduction - it is presented the scope of the standard and revealing at the same time, the need to develop it, and on the standard comes into force;

- Objective - the objective of the auditor general is to obtain sufficient appropriate evidence about the scope of the standard;

- Definitions - they have to assign appropriate meanings of terms used, in application of International Standards on Auditing; 
- Requirements - include, as a rule, audit procedures that auditor must apply to achieve the objective standard, and how to issue and reporting their findings;

- Application and other explanatory material - the auditing procedures and the issuance of findings and reporting are detailed to the provision Auditor of additional references and the insertion of annexes, where appropriate, containing models of reporting documents or other information.

In this case the review was written and International Standard on Auditing 200 "The general objectives of the independent auditor to conduct an audit of financial statements in accordance with ISAs. This standard, together with "Conceptual framework for mission assurance" is the reference of the auditor general and conceptual issues that need to consider when conducting an audit or review mission. In principle, this Standard establishes general objectives of the independent auditor when conducting an audit of financial statements in accordance with ISAs. In particular, this standard describes the aims of the auditor and explain the nature and purpose of an audit to enable the auditor to achieve these objectives. He also explained, the purpose, authority and structure of ISAs and includes requirements to establish generally applicable to all audits the auditor's responsibilities, including obligations under ISAs.

Compared with the previous version of ISA 200 introduction, in its revised form, scope contains several elements that suggests the reasons that gave rise to their introduction. Thus, there is a clear reference to the fact that the financial statements that are subject to audit are those of the entity established by management and supervision of those charged with governance. Even if it seems a situation for granted, is an important provision that configures a clear delineation of responsibility, focusing on liability management the audited entity. Also, an audit is conducted on the premise that management and those charged with governance (where applicable) clearly understand what underlies an audit responsibilities. It takes such a distinction because, in professional practice is found situations where an entity's management believes that the call to audit its financial statements diminish the responsibility on them.

The standard explicitly provides that the management and, where appropriate, those charged with governance understand their responsibilities for preparing financial statements in accordance with the applicable financial reporting, including fair presentation, where the reporting is one of accurate picture.

Another key responsibility of the entity's management refers to the organization and internal control management and, where appropriate, those charged with governance, so as to financial statements free of material misstatement due to fraud or error. It is understandable that the auditor does not involve control function entity, including the scope of internal audit. He shall only evaluate the internal control system on the one hand, and the findings may, in some cases, the internal audit findings.

Moreover, the management entity is required to allow the auditor (or provide) access to all information management and those charged with governance deems relevant to the financial statements: books, documents and other materials. The auditor may request any additional information the entity's management, for audit purposes. Also, the auditor should have unrestricted access to persons within the entity of which he considers necessary to collect evidence.

Moreover, the financial statements by management, it requires identification of the applicable financial reporting framework in the context of legislation, preparation of financial statements in accordance with it and include an adequate description of the financial statements. Meanwhile, the financial statements requires management to exercise judgment in accounting estimate as reasonable in the circumstances fiid and selecting and applying appropriate accounting policies. 
International Standards on Auditing applicable exclusively auditor. They do not impose responsibility for management or those charged with governance and not supersede the laws and regulations which establish their responsibility. Professional standards, to an audit of financial statements is to induce increasing confidence (credibility) of the target users of financial statements. In direct correlation with that purpose, increasing confidence is achieved by the auditor to express an opinion whether financial statements are prepared, in all material respects, in accordance with an applicable financial reporting framework. This is the objective of the auditor referred to earlier as the standard 200. The ISA 200, applicable from December 15, 2009, the auditor's objectives are expressed more nuanced, as it must consider two significant and interrelated issues.

First, the auditor should obtain reasonable assurance that financial statements are free of material misstatement due to fraud or error, enabling him to express an opinion whether financial statements are prepared, in all material respects, in accordance with the Financial Reporting applicable.

After the auditor obtain reasonable assurance, can and should report on the financial statements and communicate as required ISAS, based on its conclusions. Standard is a very important statement. For most financial reporting frameworks, drawn up in accordance with the included presentation. Thus, the auditor should refer to the financial requirements raporater framework when its opinion.

Another more nuanced presentation covers audit with an attitude of professional skepticism. Professional skepticism is an attitude as a professional auditor. This attitude undoubtedly varies from one auditor to another, is based on some personal characteristics such as professionalism, experience and competence. Emphasizing the personal, general auditor should show special attention to circumstances such as:

- Audit evidence that conflict with other audit evidence obtained;

- Information confinement fidelity documents and answers questions on the information used as evidence;

- Circumstances indicating possible fraud;

- The circumstances suggest the need for additional procedures to the requirements of ISAs.

Attitude of professional skepticism is evident throughout the audit, so that the auditor should not overlook the unusual circumstances, when excessive generalize findings based on the findings or use inappropriate assumptions when determining the nature, timing and extent of audit procedures and evaluate results.

Professional reasoning is another a specific feature of peofesionist accounting. At the same time, it is one of the elements that distinguished the work of a professional accountant that of other persons employed in the economy. Professional reasoning is evident in every step that the auditor is performing financial audit mission. Thus, it is necessary when determining materiality, audit risk and, according to them, the nature, timing and extent of audit procedures. Also, the judgment auditor assesses whether sufficient evidence has been obtained and appropriate and were met obiectvele ISAs and objectives of the auditor, and establishing conclusions based on evidence obtained.

These are just some of the elements that configure a new attitude on the International Accounting Standards. Its purpose is to support auditors in carrying out training missions at the highest level of quality, on the one hand, and increase public confidence in their services.

\section{Bibliography}

1. IFAC (2009), Hand-book of international standards on auditing and quality control 2009,

Editura Irecson, Bucureşti

2. www.ifac.org 